of foxes increased enormously in 1941 and remained high until October 1942, when they began to die of canine distemper. The number of cats also rose rapidly at the beginning of 1942 , but at the end of that year feline distemper caused a dramatic fall in population. Large numbers of cats were found dead or dying about the countryside during August and September. Ringworm was common in the cats in 1942 and was transmitted to station dogs and occasionally to children. These diseases would spread rapidly in such dense populations5. After the outbreaks were ended, rats, cats and foxes continued to exist at their normal low level of population.

There are in general three prevailing views about the cause of fluctuations in population ${ }^{6, ?}$. (1) They may be attributed to climatic changes, such as when exceptionally favourable conditions allow a species to take advantage of its potentially rapid rate of reproduction $8,8,10,11$. (2) The inherent instability of populations of several ecologically related species may produce oscillations quite apart from environmental changes ${ }^{12,13,14,15,16,17}$. (3) Outbreaks may be due to unnatural conditions created by the activities of man. Fig. 2 shows that three of the four plagues described above were associated with exceptionally rainy seasons ${ }^{18}$. On the other hand, the plague years 1930-31 were not especially wet, while other wet years did not have plagues. It is possible that in 1930-31 temperature or other conditions may have favoured increase. MacLagan ${ }^{19}$ has shown that over the last hundred years the frequency of outbreaks of several British insects is correlated with the periodicity of sunspots. The connecting link between sunspots and outbreaks is climatic. Each of the four plagues described above began within two years of the sunspot maximum immediately preceding it. It is possible that there may be some connexion between them; but the number of records is too few to establish either this or the contrary.

I wish to thank Mr. G. W. Moule, Government veterinary surgeon, Central West, for his kindness in sending some of the information quoted above; Mr. H. A. Longman, director of the Queensland Museum, for other information; and Mr. J. H. Pike, Agent-General for Queensland, for the loan of "Tables of Rainfalls in Queensland" (1933). My other correspondents will be nameless, but not unthanked.

${ }^{2}$ Le Souef, A. S., Burrell, H., and Troughton, E. le G., "The Wild Animals of Australia", 105 (London: Harrap, 1926).

2 Longman, H. A., Mem. Queensland Mus., 5, 23 (1916).

'Palmer, E., Proc. Roy. Soc. Queens., 2, 193 (1885).

"Troughton, E. le G., "Furred Animals of Australia", 271, 286 (Sydney: Angus and Robertson, 1941).

5 Topley, W. W. C., Lancet, 477, 531 and 645 (1936).

- Elton, C., "Voles, Mice and Lemmings" (Oxford, 1942).

"Clements, F. E, and Shelford, V. E., "Bio-Ecology" (New York: Wiley, 1939)

${ }^{8}$ Elton, C., Brit. J. Exp. Biol., 2, 119 (1924).

- Elton, C., "Animal Ecology" (London: Sidgwick and Jackson, 1927).

${ }^{10}$ Eiton, C., and Nicholson, M., J. Anim. Ecol., 11, 96 (1942).

11 Huntington, E., Science, 74, 229 (1931).

12 Cutler, D. W , Crump, L. M., and Sandon, H., Phil. Trans. Roy. Soc., B, 211, 317 (1922).

${ }^{13}$ Gause, G. F. "La théorie mathématique de la lutte pour vie" (Act. Sci. et Indr. No. 277. Paris : Herman, 1935).

${ }^{14}$ Huntsman, A. G., J. Fish. Res. Board Can., 5, 227 (1941).

${ }_{15}$ Severtzoff,-S. A., Quart. Rev. Biol., 9, 409 (1934).

${ }_{16}$ Smith, H. S., Ecol. Monogr., 9, 311 (1929).

${ }_{17}$ Volterra, V., and D'Ancona, U., "Les Associations biologiques au point de vue mathématique" (Act. Sci. et Indr. No. 243. Paris : Herman, 1935)

sones, I., "Tables of Rainfalls in Queensland", Meteorological Bureau, Brisbane (1933).

19 MacLagan, D. S., Proc. Univ. Durham Phil. Soc., 10, 173 (1941).

\title{
TROPICAL PASTURES
}

$T$ HE best grassland has depended for its existence upon a moderately cool and humid climate. Only a relative few of those familiar with the almost per. petual verdancy of English meadows and pastures realize the intensity of longing expressed in Psalm xxiii for green pastures and running waters seldom seen in a semi-arid land. In the tropics a high rainfall promotes the formation of acid soils, and a high temperature makes it difficult for most turfy grasses to form what inhabitants of temperate climates regard as a sward. Choice of tropical fodder plants is so limited that some varieties of sugar-cane are impressed into the class of forage grasses ; and most of the tropical grasses are either tall and erect, or trail to make a tangled cover, neither type of growth being so amenable as that of the grasslands of Great Britain or of the temperate lands colonized by European pasture-species.

The difficulties of establishing a pasture in the tropics are added to by an apparent lack of suitable leguminous companion plants: no legume having properties corresponding to wild white or subterranean clover has been found.

Two recent Bulletins (Nos. 31 and 32) of the Imperial Bureau of Pastures and Forage Crops at Aberystwyth deal with pasture problems. No. 31 is entirely, and No. 32 partly, devoted to problems of management in the warmer countries. No. 32 ("Advances in Grassland Husbandry and Fodder Production : a Symposium") is a miscellany, ranging from an appreciation (with bibliography) of the scientific work of R. D. Williams to a review of field experiments at Potchefstroom and a note on the fixed oil of the seeds of Trifolium subterraneum. The articles are mainly reviews or abstracts, the 'symposium' thus being a gathering of varied information which might not otherwise have been published, or, if published, might escape the attention which the compilers seem to think it deserves. There is no common thread of interest.

Under the title "The Provision of Animal Fodder in Tropical and Subtropical Countries: Part One", Bulletin No. 31 gives a succinct account of experience and hopes in the West Indies, Hawaii, Fiji, the Gold Coast, Nigeria, the Anglo-Egyptian Sudan, Zanzibar and Pemba, and Southern Rhodesia. The information it gives will be valuable not only from the purely grassland aspect but also from sociological points of view, since for example in West Africa the potentialities of change in the type of husbandry are of high social importance. That is also true of the West Indies, and indeed the paper written by D. D. Paterson with assistance from other West Indian authorities is a masterly presentation in brief of the whole problem implied by an extensive establishment of good grass. land in the tropics.

To find species that would grow at all under the given conditions has been the first thing, and with limited experimental resources it has been natural to neglect matters like those which have not received full attention in more highly developed areas.

Quality of herbage, and its effect upon livestock, is largely an open question in the tropics, few chemical analyses being available. Paterson remarks : "There can be no doubt that under tropical conditions the chances that the herbage may be lacking in some essential minor constituents are not less than in tem. perate countries. . . . After a spell in some of the other islands, racehorses reared in Tobago do not 
stand up to the strain of the racecourse as well as they do in their home island". Pressure of research in other directions is given as the reason for deferment of intensive study of the role of minor elements; but it seems fair to ask why the question of nutritional quality should be taken so fatalistically. The salary of a chemist or two would surely not be too much to add to an ordinary budget of chemical or veterinary investigation, and in conjunction with a rational policy of land use and nutrition would probably yield a high dividend.

The bulletin contains a large number of suggestive facts. Fiji has no native grass, the so-called 'native' grasses being importations which have run wild. In view of the decline of the natural indigo industry, it is interesting to learn that the cultivation of a trailing species of indigo for fodder and for purposes of soil protection is actually on the increase. What is a pest in one part of the world may be a useful grass in other parts of the world-or, as in Hawaii, in another part of one island.

HUGH NrCoL.

\section{ECOLOGICAL PRINCIPLES AND FORESTRY}

$\mathrm{O}$ N July 2, 1943, members of the forestry associations of Great Britain met at the invitation of the British Ecological Society to discuss problems arising from a paper by Sir Roy Robinson in Forestry, the journal of the Society of Foresters of Great Britain (seo Nature, 152, 196 ; 1943). A fuller account of the meeting is now available (Forestry, $17 ; 1943$ ).

Prof. A. G. Tansley, in opening the meeting, said he welcomed the desire for a closer contact between ecology and forestry. He thinks foresters would, through ecology, find much to help them to a scientific rationale of their practical operations. Prof. Tansley stresses that scientific ecology is a very young subject of research, almost entirely a product of the present century and only developed energetically since the War of 1914-18. It is in this newness of the subject that may lie the danger for the young forester. As is said, it has only been really developed since the War of 1914-18, and it is in this period that the word 'ecology' has come trippingly from the lips and pens of the young trained forester, the word being often made to serve as explanation for forestry processes as yet but dimly understood or assimilated by the junior. Prof. Tansley says: "I know very little of practical forestry, and I have often wished when $I$ was teaching forestry students their elementary botany, and always from the general point of view of ecology, that I had had a practical training both in forestry and agriculture, just as I wished I had had a practical training in medicine when I was teaching biology to medical students. For just as scientific medicine is really a branch of applied biology, so forestry and agriculture may be regarded as branches of applied ecology."

To increase our knowledge of the ecology of woodlands, Prof. Tansley suggests a "continuous opportunity for access to and study of planting experiments together with the power of suggesting different variations and forms of control which are likely to lead to increased insight into the factors at work"-in fact, research work, which all foresters would welcome. It is, however, at present, a long step from this interesting and valuable work to the ordinary practical operations of the forester based on the growth of crops to produce marketable timber. Sir Roy Robinson's explanation that in afforestation work some species are pioneers and others are successors is obviously correct. But practical research is required to show how to shorten the experimental period in new afforestation work, if such a step is economically or ecologically possible from the financial point of view.

The experienced practical forester feels that a distinction should be sharply drawn between the true ecological research point of view and its work, and the practical sylvicultural activities of the executive forester who has to acquire a working knowledge of his soils in order to undertake his duties. In other words, the danger nowadays for the younger generations of foresters is that they may be led into sylvicultural inaction pending the outcome of the ecologists' experiments, giving the latter "the power to suggest different variations and forms of control" of the sylvicultural operations of the forester. The highly efficient sylvicultural management gradually brought into being in European Continental forestry departments was not attained by such means, though such research work will always prove of value to the sylviculturist when it has been brought to the point where its practical applications will obviously lead to better results.

\section{BIOLOGICAL STUDIES IN SOUTH AFRICA}

$T$ HE South African Journal of Medical Sciences, published quarterly by the University of Witwatersrand and the South African Institute for Medical Research, is devoted to original work in any of the sciences represented in the medical curriculum. C. de V. Bevan contributes to the February 1944 issue $(9$, No. 1) an interesting article on the cultivation of the South African Rickettsiæ in developing chicks and the preparation of vaccines from the mem. branes of these. Dilute egg vaccines do not, he concludes, protect guinea pigs against epidemic infection, although they protect wholly against tick-borne in. fection and partially against endemic infection. Concentrated vaccines must be used in order to obtain complete protection against epidemic typhus produced by inoculation of guinea pigs with egg-passaged strains. A modified Machiavello technique for staining Rickettsiæ is described. The author finds that clearer staining is obtained if the smears are cleared in benzene. Bacteria and Rickettsiæ ground in a mortar with alundum are disintegrated. The development of the chick-embryo method will provide, the author thinks, smaller quantities of a far more potent vaccine than any that has yet been produced. The advantages of the egg-vaccine over the mammalian vaccines are discussed.

In the same issue, Margaret L. Creed discusses the nutritional value of a poor South African diet and of certain dietary supplements, and N. Sapeika reports on the digitalis action of a glycoside from the liliacean species Urginea rubella. More than twenty-five species of Urginea have been recorded in South Africa; many of these probably contain a toxic glycoside and a few are known to be toxic to stock. The issue concludes with a paper by O. S. Heyns and S. S. Hersch on the birth-weight of urban Bantu and the incidence among them of syphilis, still-birth and premature labour. 